\title{
Specialization without the Hospital: The Case of British Sports Medicine
}

\author{
VANESSA HEGGIE*
}

\section{Introduction: Sports Medicine and Specialism}

Specialization in medicine acts to normalize categories of health and sickness that, once constructed, can appear to be obvious and rational divisions of the body, of disease, or of populations. While the earliest work on this topic, George Rosen's sociologically informed The specialization of medicine (1944), highlighted the role of medical theory in specialty formation, historians of medicine since the 1940s have overwhelmingly argued that medical specialization is better characterized as an economic, social or political process. ${ }^{1}$ In Britain, specialization, particularly in connection with the foundation of specialist hospitals, was also a strategic approach taken by doctors competing in a vigorous medical marketplace where the advantages of professional advancement through a hospital consultancy post were monopolized by a tiny urban elite. ${ }^{2}$

George Weisz's recent work on specialization also dismisses the idea that conceptual models drove specialization. ${ }^{3}$ Yet he recognizes that medical theory did play a role in

(C) Vanessa Heggie 2010

\footnotetext{
* Vanessa Heggie, PhD, Department of History and Philosophy of Science, University of Cambridge, Free School Lane, Cambridge CB2 3RH, UK; e-mail: vh261@cam.ac.uk
}

This paper draws on research conducted while I was working on a Wellcome Trust funded project at the Centre for the History of Science, Technology and Medicine. I would like to thank Dr Ian Burney for some early suggestions, and Dr Neil Carter and Dr Malcolm Read for vital access to archive material. Writing up was facilitated by a Mellon Postdoctoral Teaching Fellowship at the Department of History and Philosophy of Science, Cambridge.

\footnotetext{
${ }^{1}$ George Rosen, The specialization of medicine with particular reference to ophthalmology, New York, Froben Press, 1944. For alternative models, see G Gritzer and A Arluke, The making of rehabilitation: a political economy of medical specialization, 1890-1980, Berkeley, University of California Press, 1985; Sidney A Halpern, American pediatrics: the social dynamics of professionalism, 1880-1980, Berkeley, University of California Press, 1988; Frank Honigsbaum, The division in British medicine: a history of the separation of general
}

practice from hospital care, 1911-1968, London, Kogan Page, 1979; Gerald Larkin, Occupational monopoly and modern medicine, London, Tavistock, 1983; Barbara Bridgman Perkins, 'Shaping institution-based specialism: early twentieth-century economic organization of medicine', Soc. Hist. Med., 1997, 10: 419-35; Rosemary Stevens, Medical practice in modern England: the impact of specialization and state medicine, New Haven, Yale University Press, 1966; Geoffrey Stuart Taylor and Malcolm Nicolson, 'The emergence of orthodontics as a specialty in Britain: the role of the British Society for the Study of Orthodontics', Med. Hist., 2007, 51: 379-98. Rosen's case study, offering an interesting reconsideration of ophthalmology, can be found in L Davidson, “'Identities ascertained": British ophthalmology in the first half of the nineteenth century', Soc. Hist. Med., 1996, 9: 313-33.

${ }^{2}$ Lindsay Granshaw, "Fame and fortune by means of bricks and mortar": the medical profession and specialist hospitals in Britain, 1800-1948', in Lindsay Granshaw and Roy Porter (eds), The hospital in history, London, Routledge, 1989, pp. 199-220.

${ }^{3}$ George Weisz, 'The emergence of medical specialization in the nineteenth century', Bull. Hist. Med., 2003, 77: 536-75; idem, Divide and conquer: a comparative history of medical specialization, Oxford University Press, 2006. 


\section{Vanessa Heggie}

the internal justifications for specialisms - in other words, such justifications were used to vindicate specialization in certain areas, rather than explaining why specialization occurred. The turn away from holism in medicine allowed diseases to be located in specific organs, tissues or cells, and so the division of medicine into specialties based on body region and disease categories seemed a rational response to the needs of practitioners working (and learning) in a field where knowledge appeared to increase year after year. ${ }^{4}$ Reconsideration of specialization in France also demonstrates that the form of specialties is dictated by the "current state of knowledge, techniques, [and] institutions" while other influences drive the process of specialization. ${ }^{5}$

So while the external motivations for specialization-economic competition, the needs of rational management and health-care policy, and other social contexts-varied over the nineteenth and twentieth centuries, the internal justifications tended to focus on reductive understandings of disease causation. In the twentieth century these explanations were supplemented by a focus on technological and treatment innovations. ${ }^{6}$ In this context, sports medicine is an extremely unpromising field to convert into a medical specialism. Sports medicine is a holistic practice, covering everything from gross musculo-skeletal injuries to dietary advice to genetic testing. It has virtually no unique diseases or injuries (one can get tennis elbow cleaning floors) nor any unique treatment modalities or technologies.

Another way to define a specialism is to claim that the patient, rather than the disease or the treatment, is in some way special. Paediatrics and geriatric medicine are justified on the grounds that the very old and the very young are different from the "normal" body public. ${ }^{7}$ Obstetrics and gynaecology are at least in part based on the understanding that women's bodies are deviant. ${ }^{8}$ While sports medicine could not identify its patients conclusively by age or gender, in the late 1940s and early 1950s sports medicine practitioners laid claim to expert knowledge based on the athletic body, which was figured as quantitatively different from the body public. ${ }^{9}$ The athlete was a discrete clinical object, a distinct patient group for two reasons, one biomedical and one social. Physiologically athletes could appear quite different from the "norms" of human life; they could have enlarged hearts, extremely low resting pulse rates, delayed menses, and so on. All these physiological features could mistakenly be interpreted as pathologies by inexperienced doctors. Secondly, the demands of athletes differed from those of non-athletes. They (allegedly) required a faster return to high levels of activity, and thus fuller functional repair, and they moved in the partly closed

\footnotetext{
${ }^{4}$ Erwin Ackerknecht, Medicine at the Paris hospital, 1794-1848, Baltimore, Johns Hopkins Press, 1967.

5 "Le processus de division en sous-espaces spécialisés est en partie déterminé par l'état existant des connaissances, des techniques, des institutions et de la structure des rapports de position des agents au sein du champ médical'. P Pinell, 'Champ médical et processus de spécialisation', Actes de la Recherche en Sciences Socials, 2005, 1/2 (156-57): 4-36, p. 4.

${ }^{6}$ Peter A Coventry and John V Pickstone, 'From what and why did genetics emerge as a medical specialism in the 1970s in the UK? A case-history of research, policy and services in the Manchester region of the NHS', Soc. Sci. Med., 1999, 49: 1227-38; Carsten Timmermann and Julie Anderson (eds),
}

Devices and designs: medical technologies in historical perspectives, London, Palgrave Macmillan, 2006.

${ }^{7}$ Halpern, op. cit., note 1 above; John Grimley Evans, 'Geriatric medicine: a brief history', Br. Med. J., 1992, 315: 1075-7; John E Morley, 'A brief history of geriatrics', J. Gerontol., 2004, 59A: 1132-52.

${ }^{8}$ Andrology has yet to be embraced as a full medical specialism in most countries, although it has had specialist journal coverage (in German) since 1969, while the American Society of Andrology was founded in 1975, the British Andrology Society in 1977, and the International Society of Andrology in 1981.

${ }^{9}$ Vanessa Heggie, A history of British sports medicine, Manchester University Press, 2010. 
world of sport where they had to live by a different set of rules. They might be unable to take certain drugs at certain times in the competitive season, and their treatments and rehabilitation had to be negotiated through other professional groups, such as trainers, team coaches and so on.

When the British Association of Sport (and Exercise) Medicine (hereafter BAS(E)M) was formed in 1952, it aimed to become the "authoritative body on every medical aspect of athletics and exercise". ${ }^{10}$ "Athletics and exercise" quickly became interpreted to mean elite and professional sport, and very little of the BAS(E)M's work in the 1950s and 1960s focused on school or community sports, or exercise for health or leisure. At the Association's first provincial meeting, in Loughborough in 1961, the theme was "Are athletes different?", a question comprehensively answered with "yes" by all the papers delivered. ${ }^{11}$ Meanwhile the executive committee of the BAS(E)M remained committed to sports medicine as an area of expertise, not a formal specialism. Sports medicine was robustly interdisciplinary, multi-practitioner, largely voluntary, and regulated through experience and enthusiasm. ${ }^{12}$ (It was, after all, an advantage for a sports doctor to have been an athlete him- or herself, a requirement of personal experience as a patient not applied to any other medical specialism.)

The first hints that this was to change appeared in the 1970s, and then with force in the 1980s and 1990s as the leadership of the BAS(E)M began actively to campaign for the formal recognition of sports medicine as a specialty in the UK, with a distinct career path and consultant positions. Sport and exercise medicine was approved as a medical specialty in the UK on 21 February 2005, entering the official register of specialties, the Specialist Order, seven months later. For nearly thirty years the leading medical organization representing sports medicine practitioners had seen no need (at least according to statements in their public records) for this sort of state-sanctioned specialization. This article will discuss the events in the 1970s and 1980s that turned a multi-disciplinary, elite, athlete-focused and experience-based model of expertise into the formalized, academic, diploma-led medical specialty that now extends into community sports and public health.

As most previous studies of specialty formation have shown, a web of interrelated causes can be credited with the shift in vision within sports medicine from the 1970s. Some of these causes are economic, some social, and others political. But what makes the story of sports medicine's specialization particularly novel is the explicit way in which the internal justification for the specialty - the athletic body_-became deeply problematic because of changes in the cultural and socio-political context in Britain. An increasing demand for, and consumption of, sports and exercise services combined with a new public health focus on

\footnotetext{
${ }^{10}$ The phrase "and exercise" was added in 1999; the adding of "exercise" to sports medicine is discussed in more detail below. Papers of the British Association of Sport and Exercise Medicine (hereafter, BAS(E)M Papers), Annual General Meeting, 27 Feb. 1953. These papers have been deposited in Archives and Manuscripts, Wellcome Library, under the classmark SA/BSM. I would like to thank Dr Neil Carter for providing me with copies.
}

\footnotetext{
${ }^{11}$ Archives of the British Olympic Association, BOA Headquarters, Wandsworth (hereafter, BOA Archives), 34.2 MED INJUR, Proceedings of meetings held at Loughborough Training College, June 1961.

${ }^{12}$ See, for example, this affirmation of the rights of "non-medical members" to sit on BAS(E)M's executive committee, vote, and hold official positions. BAS(E)M Papers, SA/BSM/A/2/2, minutes of the executive committee, 25 Sept. 1968.
} 


\section{Vanessa Heggie}

"lifestyle" to create government-backed interest in the relationship between leisure habits and health. ${ }^{13}$ In particular, exercise became a possible cure for some of the emergent diseases of civilization, while at the same time being a cause of fresh injury and disability. ${ }^{14}$

A sports medicine which was based only on elite or professional sport would fail to capitalize on these movements, and could be at risk of marginalization. British sports medicine practitioners needed to reclaim the body public as part of their patient group, and did so by adding "and exercise" to the definition of their area of expertise. In doing this they also embraced the need for specialism as a necessary part of the process of protecting an endangered area of expertise. In this article I will outline two examples of the external influences which created the pressure to specialize. First, the Sports Council's sports injuries clinic scheme of the 1970s, which highlighted all the vulnerabilities of a sports medicine based on definitions of the 1950s and 1960s; second, the economic and professional pressures of insurance and medical representation, which became particularly problematic in the 1980s. As these external factors drove the process of specialization in sports medicine, so the internal justification for the specialty also had to shift. A strong rhetoric was produced describing exercise as a drug, which should be undertaken only with expert guidance; an appeal was made for patients' right as consumers - that is, the right of everyone, regardless of their ability to pay-to access specialist sports medicine services; and an argument was made about the need to protect patients from "quacks". ${ }^{15}$

\section{The Sports Council and Sports Medicine before 1972}

The Sports Council was a significant funder of sports medicine and sports science activities from its establishment in $1965 .{ }^{16}$ One of its first executive actions, before it had even formed the committee which would subsequently handle science and medicine grants (the Research and Statistics Committee), was to award $£ 2,500$ to a joint Medical Research Council/British Olympic Association project to study the effect of altitude on athletes in preparation for the 1968 Mexico City Olympiad. ${ }^{17}$ This keen interest in elite and performance sport is indicative of the biomedical and scientific work of the Sports Council; an interest which might seem odd as the Council was the direct brain-child of an inquiry which was supposed to consider how sports "promo[ted] the general welfare of the community". ${ }^{18}$ The Wolfenden Committee on Sport was formed in 1957, and as one of

\footnotetext{
${ }^{13}$ On the public health changes, see V Berridge, 'Medicine and the public: the 1962 report of the Royal College of Physicians and the new public health', Bull. Hist. Med., 2007, 81: 286-311; idem, 'Medicine, public health and the media in Britain from the nineteen-fifties to the nineteen-seventies', Hist. Res., 2009, 82: 360-73.

${ }^{14}$ Vanessa Heggie, 'A century of cardiomythology: exercise and the heart c.1880-1980', Soc. Hist. Med., 2009 (online preview)

15 The second two justifications, an appeal to equity and to public interest, are of course familiar approaches to boundary formation in professions; they are particularly highlighted in M J D Roberts, 'The politics of professionalization: MPs, medical men, and the 1858 Medical Act', Med. Hist., 2009, 53: 37-56.
}

\footnotetext{
${ }^{16}$ The Sports Council in the period 1965-1972 is sometimes referred to as the Advisory Sports Council, to differentiate it from the Executive Sports Council, which it became in 1972. Since the Council's own records consistently use the phrase "Sports Council", this is the one I use. Centre for Sports Science and History, Birmingham University, Papers of the Sports Council (hereafter, Sports Council Papers).

${ }^{17}$ Vanessa Heggie, "'Only the British appear to be making a fuss": the science of success and the myth of amateurism at the Mexico Olympiad, 1968', Sport in History, 2008, 28: 213-35.

${ }^{18}$ Wolfenden Committee on Sport, Sport and the community, London, CCPR, 1960-1, p. 1.
} 
several recommendations published in 1960 it advised the formation of a body like the Arts Council for sport, which could channel tax revenue into both community and performance sports.

Of course, some Sports Council committees did give grants for non-elite sports activity, but when it came to sports medicine and sports science the focus was definitely not at the community level, at least until the 1970s. Between the financial years 1965/6 and 1970/1, over 90 per cent of the Research and Statistics Committee's funding was spent either on basic physiological research (including training and facilities for research) or on projects specifically focused on elite, professional and high-performance athletes. ${ }^{19}$ The only exceptions to this rule were a small grant of $£ 200$ given to a project on the assessment of fitness in schoolchildren, and sponsorship of a project on the extent and treatment of sports injuries run by Professor R C Browne, of the Department of Industrial Health at the University of Newcastle.

The desire to undertake a survey of this sort was initially couched in terms which reinforced the idea of the athlete as clinically different. D D Molyneux, an academic based in the Department of Physical Education at Birmingham University, wrote a consultation paper for the Sports Council in 1967 on the topic of sports injuries. "There are a number of reasons why sports injuries can justify separate consideration from other injuries", he argued, notably the fact that "[m]ost individuals who sustain injury through ... sports participation are anxious to return to their sport as quickly as possible." ${ }^{20}$ (This is a particularly strange justification, as it implies, of course, that other patients are not anxious to return to their normal activities "as quickly as possible".) Further, "the doctor, the physiotherapist and the trainer or coach" needed to work together to treat and rehabilitate the athlete. ${ }^{21}$ In other words, the athlete-as well as requiring special treatment-moves in a different social context, where his treatment has to be negotiated through other members of the sports community.

When this report was written, in 1967, the injured athlete had a range of options for finding specialist sports medicine treatment. Those medical members of the BAS(E)M who worked within the NHS found time to volunteer at local sports clubs or travel with the Olympic squad. Others pursued specialism in related fields such as orthopaedic surgery or cardiology, or took the Diploma in Physical Medicine, entering a specialty within which they could focus on athletes. Only a few made sports medicine a source of private income, as the paid medical officers for professional Association Football teams, in county cricket or in some other high income sports. ${ }^{22}$ There was at least one permanent clinic for athletes within the NHS, based at the Middlesex Hospital (usually for one or two days a week) since 1947; in 1966 it treated " 425 new patients and received 1,200 visits from 'old' patients in follow up cases". ${ }^{23}$ Other clinics effectively existed, but less formally as "[s]ome orthopaedic surgeons attached to various hospitals [became] known for their knowledge" and

\footnotetext{
${ }^{19}$ Taken from the Sports Council's own review of expenditure: Sports Council Papers, SC(IR)(72)1.

${ }^{20}$ Sports Council Papers, SC(RS)(67)17, 'Sports injuries-a general background to the position in Britain'.

${ }^{21}$ Ibid.

${ }^{22}$ See various oral history accounts in L A Reynolds and E M Tansey (eds), The development of
}

sports medicine in twentieth-century Britain: the transcript of a Witness Seminar held by the Wellcome Trust Centre for the History of Medicine at UCL, London, on 29 June 2007, London, Wellcome Trust, 2009.

${ }^{23}$ Sports Council Papers, Appendix A to SC(RS)(67)17, 'The Middlesex Hospital Athletes' Clinic'. 


\section{Vanessa Heggie}

therefore attracted a proportionally larger number of athletes and sports injuries to their clinics. ${ }^{24}$ Likewise, medical practitioners who were acknowledged experts in particular sports (especially boxing, rowing and swimming) or who had a paid position with football and cricket teams often treated patients outside the sport or club as well.

So the purpose of the sports injuries survey which was initiated in 1969 was to gather a statistical measure of all these varied medical interventions, and discover how many sports injuries were being treated by generalists in accident and emergency or orthopaedic units. It ran until 1972; that is, concurrently with the beginnings of the Sports Council's Sports Injuries Clinic (hereafter SIC) scheme. Opening clinics was essentially an extension of the injuries survey, with standardized patient reports allowing broader statistical conclusions to be drawn about sports injuries and their treatment. However, while the initial survey was inspired by Molyneux's claims for the special needs of the elite athlete, by the time a report was prepared on sports injuries the Sports Council appeared keen to present them as a "broad community problem", whose patients were "ordinary club or casual players, of socio-economic grade $\mathrm{C} 1 \ldots$... [m] any were students and school-children". ${ }^{25}$

The reason for this shift in focus, although it is not made explicit, probably lies with the reformation of the Sports Council in 1972, when it was recreated as an executive body. As part of this process it absorbed some of the responsibilities and finances of the Central Council of Physical Recreation (founded in 1935 as the Central Council of Recreative Physical Training). The CCPR had originated out of fears about national fitness in the interwar period, and had long focused on school sports and exercise for health and leisure. ${ }^{26}$ Inevitably the transfer of staff and responsibilities to the Sports Council led to some new avenues of interest in community and leisure sport. Meanwhile, sports medicine became established in the committee structure of the new Council: the chair of the Research and Statistics Committee, Roger Bannister (both a sportsman and a doctor), became the chair of the whole Council, while the new chairmanship of the Research Committee went to Peter McIntosh, then a key figure in the running and founding of the Institute of Sports Medicine. ${ }^{27}$ These adjustments of outlook and personnel overlapped with a shift in public health policy in the UK, detailed elsewhere by Virginia Berridge. ${ }^{28}$ This more interventionist approach focused on lifestyle reforms inevitably increased interest in the possible use of exercise and sport to promote health.

In the following section I will outline the Sports Council's Sports Injury Clinic scheme, and show how it revealed sports medicine as a vulnerable medical specialty in the new socio-political climate of the 1970s. While there is no evidence that this scheme was intentionally threatening, and the undermining of British sports medicine's internal justification for specialism may have been entirely accidental, it was the start of a period of external and internal threat and subsequent reform which fundamentally changed British sports medicine into the formal specialty of Sport and Exercise Medicine.

${ }^{24}$ Sports Council Papers, SC(RS)(67)17.

${ }^{25}$ National Archives, Kew (hereafter NA), MH166/1394, the Sports Council Pilot Study of Sport Injury Clinics.

${ }^{26} \mathrm{H}$ Justin Evans, Service to sport: the story of the CCPR, 1935-1975, London, Pelham for the Sports Council, 1974; Barrie Houlihan, The government and politics of sport, London, Routledge, 1991, pp. 86-91.

${ }^{27}$ The Institute of Sports Medicine was founded in 1963 as the "academic" wing of British sports medicine by the BAS(E)M, the British Olympic Association and the Physical Education Association.

${ }^{28}$ Berridge, op. cit., note 13 above. 


\section{Sports Injuries Clinics}

In 1967 Bannister, then still the chair of the Research and Statistics Committee of the Sports Council, had a meeting with the government's Chief Medical Officer, George Godber. The topic was sports injuries clinics, or rather the need to gather statistical information about the demand and need for specialized treatment in the UK. ${ }^{29}$ This, plus Molyneux's briefing document, inspired the project grant to Browne, of $£ 1,000$ in the first instance, which was increased as the project was extended in the early 1970s. ${ }^{30}$ The project involved a survey sent to sports clubs and athletes, which was supposed to provide figures on the prevalence and bodily location of sports injuries, list the treatments given, and make some estimation of the social cost of injuries (in terms of time off work, etc.). At first only injuries in rugby and football were considered, with the terms of reference extended in 1971 to eleven other sports, from amateur boxing to diving. ${ }^{31}$

Armed with more facts and figures on the prevalence, and apparent poor treatment, of sports injuries, Bannister approached Godber again in $1971 .^{32}$ Godber subsequently appointed a small group of civil servants to investigate the possibility of forming SICs within the NHS. ${ }^{33}$ Even at this point the representatives of the DHSS were firmly sceptical about claims that athletes needed or deserved special treatment. The leading figure in the DHSS's inquiries, Dr Michael J Prophet, suggested that there were actually two reasons why sports injuries appeared to get poor treatment. It was possible that athletes needed specialist treatment, which was not comprehensively available on the NHS, but it was more likely, he suggested, that there was a general failing in the treatment of soft tissue injuries of all kinds. With these ideas in mind he set out to visit "a few places to see how injuries and particularly sports injuries are managed and to discuss with the clinicians the needs in this area". 34

Prophet interviewed Browne, four surgeons (mostly in orthopaedics) who were known for working with athletes, and the current and ex-honorary secretaries of the BAS(E)M, Dr Peter Sperryn and Dr J G P Williams. He also spoke to representatives of the British Olympic Association. What Prophet and the other civil servants involved in the SIC project found overwhelming was the level of "politics" involved in sports medicine. Briefed and counter-briefed by tense practitioners, and aware of competing interests in health and sport at the highest ministerial levels, one adviser wrote to another that "the politics surrounding this subject are diverse and deep. I have been warned to tread warily". ${ }^{35}$

\footnotetext{
${ }^{29}$ Sports Council Papers, SC(RS)(68)3, note of a meeting held at the Ministry of Health, 19 Nov. 1967.

${ }^{30}$ Sports Council Papers, SC(RS)(69), Research and Statistics Committee Minutes, 8 July 1969.

${ }^{31}$ Sports Council Papers, SC(RS)(71)22, 'A proposal from the Nuffield Department of Industrial Health ... for an extension of the pilot study on sports injuries', 11 June 1971.

${ }^{32}$ NA, MH166/1394, letter from Roger Bannister to George Godber, 27 Oct. 1971; Notes of a meeting re. Sports Injuries, 26 Nov. 1971.

${ }^{33}$ It is not clear from the archive material exactly who was involved in this group, which appears
}

to have been put together relatively informally. Correspondence about the issue is shared between four doctors: Dr M J Prophet, Dr Catherine N Dennis, Dr Archibald and Dr Yellowlees.

${ }^{34}$ NA, MH166/1394, letter from Dr C N Dennis to Drs Archibald, Yellowlees and M J Prophet, 3 Dec. 1971.

${ }^{35}$ NA, MH166/1394, letter from Dr M J Prophet to Dr C N Dennis, n.d. (early 1972). See also a handwritten note from Dr M J Prophet to Dr Laylock, 20 Dec. 1973, "The politics, the suggestion of rivalry among the groups associated [with] Sport is incredible. We must proceed [with] care + caution". 


\section{Vanessa Heggie}

The consensus of all the witnesses was that the Sports Council's scheme was a bad idea, although they had quite different reasons for arguing this case. On the one hand, the surgeons said (as Prophet had expected they would) that if sports injuries were not getting the care they needed, then this was symptomatic of a general failure in accident and emergency, soft tissue and orthopaedic services. If money and will were available, they should be put towards improving these services for everyone, rather than picking out a select part of this patient group for special treatment. On the other hand, the sports doctors offered objections which were more specific to the planning and organization of the Sports Council's scheme. Sperryn "felt that the [demand] for general physical medicine was such that time and space did not allow for an extra load" ${ }^{36}$ Williams argued more bluntly that there were not enough sports medicine experts available in the UK for a large enough SIC programme to be set up, and that to run such SICs without expert supervision would invalidate the results produced.

The DHSS team therefore remained to be convinced that athletes deserved special treatment, since, as Prophet wrote around 1971: "I would personally give priority to a window cleaner with a sprained ankle sustained at work over a bank clerk with a similar injury that occurred in a football match." ${ }^{37}$ If they did need special treatment this should be provided privately, not on the NHS: "[I]t would probably be sensible for an individual, especially if he were a professional sportsman, to take out an insurance policy to cover all eventualities if he feels that he merits special attention." ${ }^{38}$ The Sports Council, however, remained committed to a SIC scheme, which they decided to pursue even without formal support from the DHSS.

To understand the reason for the Sports Council's persistence, it is important to remember that the SIC scheme was discussed by the Council as if it were a corollary to Browne's work; it is described as a "supplementary project ... look[ing] at the same problem from the hospital end". ${ }^{39}$ These clinics were not primarily intended to provide treatment and cure (though that was a welcome side-effect), but rather to produce facts and figures on the types and extent of injuries, the sorts of people who would make use of such clinics, and the social cost of sports injuries. This is a crucial point in understanding the difference between the Sports Council's and the BAS(E)M's conceptualizations of a SIC at the time. Although the Sports Council "hoped that the clinics themselves [would] provide quicker and better treatment for injured sportsmen than is currently available ... [t]he ultimate purpose of the project is to make out a case for improved treatment of sports injuries in particular, and soft tissue injuries in general". ${ }^{40}$

The agreed model for a Sports Council SIC, as laid out in documents from February 1972, would run as if it was "a 24-hour casualty department, under a consultant orthopaedic surgeon with an interest in sports injuries, where injured sportsmen can be seen quickly ... [with a] quick referral to a consultant in physical medicine working at the same hospital". ${ }^{41}$ This schema acted to disqualify a large number of active members of the BAS(E)M. It

\footnotetext{
${ }^{36}$ NA, MH166/1394, letter 'Special clinics for athletes' from Dr M J Prophet to Drs Archibald and Yellowlees, 4 May 1972.

${ }^{37}$ NA, MH166/1394, letter from Dr M J Prophet to Dr C N Dennis, n.d. (c.1972).

${ }^{38}$ Ibid.
}

\footnotetext{
${ }^{39}$ Sports Council Papers, draft copy of the annual report 1972-3.

${ }^{40}$ Sports Council Papers, SC(IR)(73)6.

${ }^{41}$ NA, MH166/1394, letter from B J Rees (Sports Council) to Dr Ower (DHSS), 25 June 1973.
} 
excluded anyone working in the community, outside hospitals; more significantly it placed control directly in the hands of surgeons rather than physicians or other specialists-this at a time when BAS(E)M members were as likely to be physiotherapists as they were surgeons. ${ }^{42}$ Williams, for example, was not invited to take part in the scheme; as a practitioner in a rehabilitative unit he did not qualify under the criteria. Sperryn turned down an invitation to participate; as a consultant in physical medicine he could have taken referrals from a SIC, but did not believe the Hillingdon orthopaedic surgeons would be interested in joining the Sports Council scheme.

The failure to involve either Williams or Sperryn is interesting given that both were actively running their own SICs at this time, as were many other BAS(E)M members, few of whom had anything to do with the Sports Council's scheme. When the DHSS was still investigating the matter, Prophet had drawn up a list of men he considered national experts in sports injuries-in 1972 this consisted of just eight names. ${ }^{43}$ Of these, only two were included in the Sports Council's SIC project. Although a clinic was opened at Guy's, it was not organized by the local expert, Hugh Burry (an ex-All Black, FRCP, and convener of the BAS(E)M's research group on Sudden Death in Sport), at least in part because he was a consultant in physical medicine, and not a surgeon, although he did give "advice on the administrative aspects of the clinics' operations". ${ }^{44}$

Initially, the Sports Council budgeted $£ 4,250$ to cover the administrative costs of six to eight clinics, all of which had to agree to use standardized patient record forms. Eventually a dozen clinics were opened, but of these half closed within five years. Worries voiced by BAS(E)M members about the stability and reliability of clinics not staffed by sports medicine enthusiasts seemed well founded. 1,636 patient records were returned on a standardized form, and in 1974 the Sports Council employed the medical statistician Dr K Kingsbury to analyse these results.

\section{Sports Injuries vs. Sports Medicine}

Kingsbury published the results of the SIC scheme in a long report, The Sports Council pilot study of sport injury clinics in 1976. A third of patients had sustained their injuries playing football, nearly a quarter playing rugby, and a little over a sixth during athletics. Most emphatically these were amateur sportspeople, "ordinary club or casual players ... Many were students and school-children ... only $8 \%$ were international and $3 \%$ professional players". ${ }^{45}$ Professional and international players, and patients in higher socio-economic groups were clearly getting different sorts of sports medicine; young people and "less serious sportsmen" were found more often in the SICs in casualty departments compared with the wealthier and "more serious" sportsmen, whose GPs tended to refer them to rheumatology

\footnotetext{
${ }^{42}$ Of a list of just over 450 BAS(E)M members from 1968, of those whose qualifications are stated, over 150 were physicians, and between twenty and twenty-five either surgeons or members of the Association of Chartered Physiotherapists. Anon., 'List of members', British Journal of Sports Medicine (hereafter BJSM), 1968, 3: 96-104.

${ }^{43} \mathrm{Mr} J$ Buck (Brook General Hospital), Dr H Burry (Guy’s), Dr I Curwen (Queen Mary's),
}

\author{
Mr A McDougal (Victoria Infirmary, Glasgow), \\ Dr K Lloyd (United Cardiff Hospitals), Dr J Blonstein \\ (Amateur Boxing Association), Dr P Sperryn, \\ Dr J G P Williams. NA, MH166/1394, letter from \\ Dr M J Prophet to Dr C N Dennis, 14 June 1972. \\ ${ }^{44}$ Sports Council Papers, SC(IR)(73)6. \\ ${ }^{45}$ NA, MH166/1394, 'The Sports Council pilot \\ study of sport injury clinics', p. 58.
}




\section{Vanessa Heggie}

or orthopaedic units. The athletic body was, it appeared, already getting specialized treatment:

Professional players seem to have found some answer[s] ... They stood out as a group with a much shorter average history of symptoms, less incapacity and fewer chronic lesions. This suggests that their need to return to sport quickly had established an awareness of the value of expert, hospital attention, and where to obtain it. ${ }^{46}$

The report's overall conclusion is that sports injuries were "a broad, community problem". ${ }^{47}$ "The difficulty appears to lie", argues the report, "in the routine care of acute soft tissue injuries as a whole, rather than in the care of sport injuries specifically." 48 The Sports Council tried to reformulate this to promote, still, the idea of SICs, suggesting that they could perform a useful function by gathering together experts in soft tissue injuries and rehabilitation, and forming a locus for the standardization of treatment and the proper followup of injuries. Sports, they argued, caused a disproportionate number of such injuries, and therefore athletes suffered disproportionately because of the poor treatment of these lesions in the NHS.

The DHSS was unconvinced, especially about the value of naming such places "sports injuries clinics" if they were really "soft tissue injury clinics". "In these hard times," wrote one DHSS representative, the title 'Sports Injuries Clinic' "could be seen as a way round the orthopaedic waiting lists, and experience surely should be available to all who need it". ${ }^{49}$ In addition to their unwillingness to draw special attention to a group of patients who did not share a specific lesion or disease, the DHSS was also wary of the "politics" of sports medicine: "[T]here are people who are pressing for 'Sports Injury Clinics' who are not necessarily totally persona grata. Thus the name tends to get muddled with the personality." 50

The instability and short-lived nature of many of the Sports Council's SICs meant that as physical institutions they were no threat to the better established and longer-running informal SICs and "ghost clinics" provided for all levels of sportsmen and women by the members of the BAS(E)M. The scheme did, however, have an important impact on the organization and self-recognition of sports medicine in Britain, and was, as I will argue, a key factor in the shift between the sports medicine of the 1950s and 1960s, and the specialty of Sport and Exercise Medicine as it was redefined in the 1980s and 1990s. The first challenge the SIC scheme posed was one of authority and territory within the British political sphere. The second, more subtly, was a challenge to the internal, rhetorical, justification for sports medicine as a discrete area of medical expertise.

Although the Sports Council repeatedly described the SIC scheme as a fact-gathering exercise, which could be used to encourage the NHS to provide sports medicine to the public, the practical ramifications of the scheme were that the Council was engaging directly in the organization and provision of health care. This was clearly edging into the territory

${ }^{46}$ Ibid., p. 61.

${ }^{47}$ Ibid., p. 68.

${ }^{48}$ Ibid., p. 62.

${ }^{49}$ NA, MH166/1394, letter from Dr Jane Richings to Miss P M C Winterton, 28 Jan. 1976.

\footnotetext{
${ }^{50}$ NA, MH166/1394, letter from Dr Nichols to Dr Jane Richings, 1 March 1976.
} 
which had previously been the entire domain of the BAS(E)M. Further, through its close engagement with the DHSS, and more successfully with the Department of Environment (where the Minister for Sport and Recreation was based), the Sports Council established its position as a consultative body for sports medicine and sports science in the UK. ${ }^{51}$ By 1976, when the British Government was asked to respond to a questionnaire sent by the Council of Europe about sports medicine provision, the DHSS decided that

since the Sports Council is a semi-official body and has recently been taking a considerable interest in this subject, it would be adequate to take advice from them, rather than going to the [BAS(E)M] and the International Federation of Sports Medicine, both of which bodies have vested interests in what the Council of Europe recommends. ${ }^{52}$

That the Sports Council might become the body which automatically received governmental inquiries about sports medicine was clearly a worry for organizations like the BAS(E)M. Even worse, the outcomes of the SIC project seemed to portray a form of sports medicine with ominous repercussions for the future of the discipline in the UK. The Sports Council had drawn the DHSS's attention to sports medicine, but then singularly failed to demonstrate that it was a real or natural division of medicine which should concern the NHS. The Department appeared convinced at the end of the project that the public needed better general soft tissue services, while the elite athlete—if he or she needed "special" treatment at all—could, if necessary, purchase private health care.

A second problem was use of the hospitals as focal points. Of the twelve Sports Council SICs, eleven were based in hospitals, while one was at the Joint Service Medical Rehabilitation Unit in Surrey. The importance of the hospital to claims for specialty status is well documented elsewhere, as is the 150 -year conflict between the community practitioner and the hospital consultant. ${ }^{53}$ Of Prophet's list of sports injuries experts a quarter were based in the community. Presumably had his list been of sports medicine experts, this proportion would not only have been larger but would also have contained people who were neither doctors nor surgeons. The Sports Council's decision to consider sports clinics only in the hospital rather than in rehabilitation centres, GP practices or other community sites (i.e. sports centres) was complicated by its insistence that these clinics should be headed by a surgeon. Again, of Prophet's list of sports injuries experts, six of the eight were physicians, not surgeons. The BAS(E)M, of course, represented orthopaedic surgeons and hospital consultants in other fields, but it was also an important spokes-organization for physiotherapists, rheumatologists, general practitioners and many other medial professionals who found themselves at the margins of, or entirely excluded from, the Sports Council's project.

\footnotetext{
${ }^{51}$ The attitude of the Department of the Environment, and particularly of Denis Howell, Minister of Sport and Recreation, 1974-9, to the SIC scheme was quite different to that of the DHSS. Howell's advocacy of the NHS's role in providing sports medicine (and not just sports injuries care) did not always match the line taken within the DHSS itself. See, for example, NA, MH166/1394, letter from Dr Archibald to Dr J Richings, 24 June 1976, and the various materials relating to the Department of the Environment's records on Research into Sport, Exercise and Health: NA, AT60/65.
}

\footnotetext{
${ }^{52}$ NA, MH166/1394, letter from Miss P M C Winterton to Mr Hertzmark, 10 May 1976.

${ }^{53}$ Anne Digby, The evolution of British general practice, 1850-1948, Oxford University Press, 1999; Granshaw, op. cit., note 2 above; Honigsbaum, op. cit., note 1 above; C Lawrence, 'Incommunicable knowledge: science, technology and the clinical art in Britain, 1850-1914', J. Contemp. Hist., 1985, 20 : 303-20.
} 


\section{Vanessa Heggie}

Finally, there was the reduction of "sports medicine" to "sports injuries". By the 1970s the BAS(E)M represented a diverse range of medical practices as well as practitioners. Not only did the Sports Council's model effectively disenfranchise significant parts of the sports medicine community, but it was also using its relationship with government to promote an image of sports medicine which was actively unhelpful to the BAS(E)M's future plans. The danger was that the Kingsbury report could be-indeed was by the DHSS - interpreted to mean that the average person had no need of sports medicine services, and that these, as a specialist service, had no place in the NHS. From this viewpoint, sports medicine for the body public could be disaggregated into orthopaedic surgery, general rehabilitation and better soft tissue injury treatment, while specialist services would be targeted at a limited and more and more refined pool of elite athletes, probably via private insurance and without the NHS. ${ }^{54}$

This was not the specialism envisioned by the BAS(E)M, and its members immediately began to refute the conclusions of the Sports Council. Sperryn and Williams were amongst the first BAS(E)M members actively to take this on, co-writing a widely cited article in the British Medical Journal in 1975 arguing that the problem of sports injuries "[c]annot effectively be solved by the organization of special clinics for sportsmen based on existing services. There is a case for establishing regional or area clinics manned by appropriately trained, recognized, and committed specialists". ${ }^{5}$

This model of new, specialized clinics, staffed by "specialists" (not general orthopaedic surgeons), was the dominant one promoted by the BAS(E)M as it began to argue for sports medicine to become a formal specialty. The suggestions that, firstly, the lay body did not need sports medicine experts, and, secondly, that the athletic body could be adequately served by the private health-care industry were also countered, and I will turn to those debates shortly. Before that I will briefly discuss further threats to BAS(E)M-style sports medicine, an economic threat from without, and a professional threat from within.

\section{Regulating Sports Medicine: Insurance and BATS}

The Sports Council's scheme was not the first attempt to open sports clinics in the UK. In the late 1950s the BAS(E)M had tried to organize a SIC at the Middlesex Hospital to run on Saturday evenings for patients who were able to bring "a note from [their] Secretary or Captain". ${ }^{56}$ This was clearly aimed more at organized amateurs than leisure sports, and ran for only a year, closing in 1958 due to low attendance at the weekend. The Middlesex Hospital was chosen as it was already the site of what was probably the first NHS sports injuries clinic, founded by the Accident Officer Dr Woodard, who was also involved with the Amateur Athletics Association. ${ }^{57}$ Specialist facilities for elite or professional players certainly

\footnotetext{
${ }^{54}$ The vision of the Sports Council and the BAS(E)M was more successfully drawn together in the late 1970s; see NA, AT60/65.

${ }^{55} \mathrm{P}$ N Sperryn and J G Williams, 'Why sports injuries clinics', Br. Med. J., 1975, 3: 364-5, on p. 364, emphasis added.

${ }^{56} \mathrm{BAS}(\mathrm{E}) \mathrm{M}$ papers, SA/BSM/A/2/1, minutes of the executive committee, 29 April 1957.
} 
pre-date this clinic; by the inter-war period most (professional) Association Football clubs engaged a medical officer and employed a range of medical auxiliaries for the treatment of their players, sometimes in very extensive rehabilitation "clinics" or rooms at their home ground. ${ }^{58}$ In the late nineteenth century a hydropathic institute at Matlock House, Manchester, became so well known for its athlete-centric treatments that it was popularly referred to as the "footballers' hospital", treating the strains and sprains of footballers and other sportsmen with a range of physical, pharmacological and psychological approaches. ${ }^{59}$

Specialized facilities were the exception rather than the rule for most of the twentieth century as access to expert care was largely limited to professional and "serious" athletes. This changed after 1970 with a boom in sports medicine clinics, many outside the NHS, catering as often to the amateur exerciser as to the elite performance athlete. Sports injuries clinics, a text-book on the treatment of common sports disorders, published in 1984, lists in an appendix twenty-eight NHS sports injuries clinics, alongside fifteen "private" physiotherapy clinics which specialized in sports injuries. ${ }^{60}$ In 1986 Running Magazine published its own "selection" of sports medicine clinics, listing thirty NHS and thirty-three private medical clinics, alongside fifteen private physiotherapist-led facilities. ${ }^{61}$ Around the same time, the BAS(E)M organized a survey of clinics, publishing its Register of Sports Injury and Physiotherapy Clinics in 1987, listing 137 centres across the country. In the second 1990 edition 250 clinics were listed, with "more details" on 220 of those appearing in the third edition, published in $1993 .{ }^{62}$

These clinics ranged widely, with those in the NHS typically being temporal rather than physical (i.e. specifying a particular time when sports injuries would be prioritized) or based on personnel (an in-house expert would be preferentially allocated sports medicine queries). Private clinics could be more extensive and permanently available. Some clinics also had strong academic and research links; 1978 saw the founding of a SIC at the University of Manchester, for students in the first place, but eventually taking in local athletes of international standing. ${ }^{63}$ The first Sports Medicine Fellow, Dr Sylvia Lachmann, was also appointed in 1978 to New Hall (now Murray Edwards College), Cambridge, leading to the formation of an associated SIC at Addenbrooke's Hospital. ${ }^{64}$

While those running clinics within the NHS complained about the lack of support, those outside the NHS faced even more serious threats. In particular, the ambiguous status of sports medicine caused problems with medical insurance companies, as many firms struggled to rationalize their payouts for sports medical treatment. As an example, in 1984 the New Allied Medical Insurance Company asserted that their usual policy was to recognize a doctor as a specialist only if he or she held or had held a consultancy post in an NHS hospital; this could exclude many expert sports medicine practitioners, as there were no

\footnotetext{
${ }^{58}$ D F Featherstone, 'Medicine and sport', Practitioner, 1953, 170: 299-302; W G S Pepper, A T Fripp and W E Tanner, 'Injuries to the professional association footballer', Practitioner, 1950, 164: 298-305.

${ }^{59}$ M Randal Roberts, 'A footballers' hospital', Windsor Magazine, March 1899: 511-16.

${ }^{60}$ John King (ed.), Sports injury clinic, London, Pelham Books, 1987.
}

\footnotetext{
${ }^{61}$ Anon., 'How to find a sports injury clinic', Running Magazine, 1986, 68: 46.

${ }^{62}$ P Sperryn, 'Editorial: BASM's clinic register', BJSM, 1993, 27: 219.

${ }^{63}$ C S B Galasko, et al., 'University of Manchester Sports Injury Clinic', BJSM, 1982, 16: 23-6.

${ }^{64}$ NA, FD23/4515, 'Medical research and sport', outline proposals for the Cambridge project, n.d.
} 


\section{Vanessa Heggie}

consultant posts in "sports medicine", and most BAS(E)M members did not hold consultancies. ${ }^{65}$ Individual practitioners were able to negotiate recognition in a variety of ways, but regular moments of status insecurity-most acute for those who relied on private health-care payments for their entire income-obviously inspired a desire to find some standardized way to identify experts in sports medicine.

The market in sports medicine clinics also caused some of those who did not have to rely on income from private health plans to argue for formal systems of recognition. Since it was not a specialism, anyone with an appropriate medical qualification could claim expertise in sports medicine, and there was no compulsion or obligation for them to join the BAS(E)M. According to established sports medicine practitioners, the public needed protecting from "unqualified 'back street' sports injuries clinics" ${ }^{66}$ It was essential to safeguard sports medicine's reputation as some articles began to be published criticizing it as a "pseudospecialty", based on the false premise that sportsmen and women formed a coherent patient sub-category. ${ }^{67}$ Without formal regulation or a specific educational path it was reputed to "harbou[r] some quacks and charlatans". ${ }^{68}$ The pressing question was: who or what should be the arbiter of quality in sports medicine?

The BAS(E)M's embrace of scientists, physiotherapists and sporting professionals as members placed limitations on its ability to function as a direct representative of and, if necessary, advocate for, registered medical practitioners. As demand for systems of recognition and regulation grew, so did pressure for the formation of an organization that could specifically guard the interests of doctors. The first attempt to do so was closely associated with the problems of insurance payments in the private sector. In 1980 the British Association of Trauma in Sport (BATS) was founded by four BAS(E)M members. The aim was to "fill a vacuum because [BAS(E)M] had no teeth or capacity to provide sports medicine to the injured athlete ... building up [to full primary care] step by step from a small start with soft tissue injuries". ${ }^{69}$ This was to be achieved through a non-commercial insurance scheme run through a "completely professional body"-i.e. the BATS—open only to registered medical practitioners. ${ }^{70}$

The BATS was immediately contentious. The honorary secretary of the BAS(E)M, Peter Sperryn, used his column in the British Journal of Sports Medicine to query the probity of the four founding members, who were all also medical advisers to an insurance company which would be providing the medical insurance organized by the BATS.$^{71} \mathrm{He}$ seemed to be suggesting that the overlap between those who would decide who was and

\footnotetext{
${ }^{65}$ Personal papers of Dr Malcolm Read, letter from New Allied Medical Insurance Co. to Malcolm Read, 19 Jan. 1984. I would like to thank Dr Read for allowing me access to his collection of materials relating to sports medicine.

${ }^{66} \mathrm{~J}$ E Davies, 'Sports injuries and society', BJSM, 1981, 15: 80-3.

${ }^{67}$ R G Pringle, 'Dangerous, meddlesome, wasteful ... sports medicine is a pseudo-specialty', World Medicine, 22 March 1980: 29-30.

${ }^{68} \mathrm{~J}$ Jones, 'Sports medicine and soft tissue lesions', in Hedley Berry, Eric Hamilton and
}

John Goodwill, Rheumatology and rehabilitation, London, Croom Helm, 1983, pp. 127-38, on p. 137.

${ }^{69}$ BAS(E)M Papers, SA/BSM/A/2/2, minutes of the executive committee, 12 Jan. 1981.

${ }^{70}$ Members of the Association of Chartered Physiotherapists in Sports could become associate members.

${ }^{71}$ P Sperryn, 'Secretary's column: unity or fragmentation?', BJSM, 1981, 15: 88-9. 
who was not an "expert" and those who stood to profit by a successful insurance scheme was unethical, although he was forced to withdraw his statements in a later edition of the journal. Debates at BAS(E)M meetings about the BATS were heated, and in some cases deliberately unminuted. In fact, the insurance scheme collapsed, and the BATS itself was of limited long-term impact. Its founders claim that it had 150 or 160 members at its peak, and ran until the late 1980 s with conferences and symposia. ${ }^{72}$ Others point out that less than 10 per cent of the membership turned up to most meetings. ${ }^{73}$ What the BATS did do was, like the Sports Council's SIC scheme, to throw a spotlight on the most vulnerable points of sports medicine's organization and practice in Britain at the time. The issue of recognition, formal or otherwise, and the issue of doctor representation became central in the later 1980s.

While the debates about the BATS were ongoing, the executive committee of the BAS(E)M drew up a paper to consider the long-term future of the organization, which was extensively discussed by the Association in 1982. The vision was federalism-instead of a single mouthpiece, the BAS(E)M would become an umbrella organization collecting together fractured special interest groups with common ground in sports medicine. Many professional groups were gaining separate organizations for sports medicine (for example, the Association of Chartered Physiotherapists in Sports Medicine, founded in 1972), while doctors were one of the few groups not specifically represented anywhere. This federal dream of the BAS(E)M, where organizations like the Association of Chartered Physiotherapists in Sports, and even the BATS, could be brought under one superstructure, was never realized. Yet, through the last decades of the twentieth century and into the twenty-first, specialist groups were repeatedly founded; as recently as 2001 an attempt to turn the BAS(E)M into a doctors-only organization led to the formation of the United Kingdom Association of Doctors in Sports (UKADIS). In his 'Case for [the BAS(E)M] to become a membership organization ... for doctors', one co-founder makes the point clearly that "the only group not represented in their own right (in sports medicine) are the doctors". ${ }^{74}$ And while doctors did not gain a specialist group, they did gain a specialty that protected their professional interests.

\section{Specialty: From Sports Medicine to Sport and Exercise Medicine}

The underlying changes that moved sports medicine from an area of expertise to a formal medical specialty were essentially social. An increase in the proportion of the population taking part in organized or regulated sporting activity can, paradoxically, go hand-in-hand with an increasingly sedentary population, where exercise for health has become a core part of the public health message. And the sports which people were engaging with were often relatively high-performance; fewer than a dozen annual marathons were run in England before 1970, with 26 in 1980, rising to 47 when the first London Marathon was run in

\footnotetext{
${ }^{72}$ Reynolds and Tansey (eds), op. cit., note 22 above; see the evidence of Dr Davies in particular.

${ }^{73}$ BAS(E)M Papers, SA/BSM/A/2/2, minutes of an executive committee meeting, 23 June 1982.
}

\footnotetext{
${ }^{74}$ BAS(E)M Papers, SA/BSM, 'The case for BASEM to become a membership organisation in sport and exercise medicine for doctors' by Malcolm Read and Nick Webborn.
} 


\section{Vanessa Heggie}

1981 - this had more than doubled to 115 marathons by $1983 .{ }^{75}$ As Sperryn and Williams wrote in 1975, "Sport for All" inevitably meant "sports injuries for all", which should mean "sports medicine for all" - not just for injuries, but also, eventually, advice on training and diet for the vastly increased numbers of long-distance runners, evening squash players and weight-reducers. ${ }^{76}$

But while the external influences on sports medicine were entirely contextual, some internal justifications followed familiar patterns in the history of specialization. The regulation of SICs, even though they represented only a fraction of the activity of sports medicine, was important because it both reacted to the need to prove status to insurance companies (a clear economic pressure) and adjusted the public image of sports medicine by eliminating the "quacks". It was the latter argument-public protection-which appeared most prominently in public discussions; protecting the public from charlatans and their "back street clinics" is part of a very long tradition of medical professionalization. ${ }^{77}$ None the less, the role and significance of private health care and insurance in sports medicine made it particularly sensitive to competitive drives and commercial pressures, perhaps more so than other specialisms in the UK. The DHSS seemed content, suggesting that general health care could cope with the demand for sports medicine for the lay body, with specialist treatment dealt with through club finances or personal insurance. The BAS(E)M, on the other hand, proposed a more comprehensive arrangement, with sports medicine fully embedded for all within the NHS, and properly regulated in the private market.

One way to justify sports medicine's place in the NHS was to frame it as part of a larger argument about equity and access. Begging the question of whether it was a specialty at all, the argument was made that given it was a specialty it should be available to everyone. In particular, at a time when some government departments were recommending that the whole population should do more exercise, other departments should not be refusing specialist care. This point was perhaps most unequivocally spelt out in a 1994 British Journal of Sports Medicine editorial which claimed that the "government [was] hell-bent on crass materialism and the recreation of Dickensian poverty in the re-emerging underclasses", in a society where "[p]ride in public provision is eroded by yuppy [sic] health gyms, expensive squash, golf and swimming (and private sports medicine)" ${ }^{78}$ It goes on to claim that privatization rarely leads to cheaper facilities, and asks, "[h]ow are the underprivileged to play sport? ... what about the 'health' aspects of 'sport' as we drop 'for all'?"

A full discussion of the impact of changing public health policies and of the notion of exercise for health on British sports medicine deserves its own article. The responsibility of a government to provide care to support the exercise it was promoting fed into the third change in the way sports medicine was featured in this period, which I have discussed at more length elsewhere; a rhetoric of drugs, prescriptions and doses was applied to exercise. ${ }^{79}$ This rhetoric described sports participation and gym use as an area of expert knowledge, which

\footnotetext{
${ }^{75}$ Centre for Sports Science and History, Birmingham University, NCLA II.M203. $\mathrm{N}$ McGuinness, 'A study of the temporal and regional aspects of the English marathon between 1908 and 1985, with suggested explanations for trends uncovered', Birmingham, Social Sciences dissertation, n.d.
}

\footnotetext{
${ }^{76}$ Sperryn and Williams, op. cit., note 55 above.

${ }^{77}$ See, in particular, Roberts, op. cit., note 15 above.

${ }^{78}$ P Sperryn, 'Sport for all—or all for sport?', BJSM, 1994, 28: 219.

${ }^{79}$ Heggie, op. cit., note 14 above.
} 
could literally be prescribed to a variety of patient groups. Used successfully, exercise promoted health; used wrongly, overused, or used inappropriately, exercise could cause disease, injury and even death. This was a powerful way for practitioners whose specialism was based on the concept of an elite athletic body to extend their expertise and knowledge to the wider body public.

\section{Conclusion}

Weisz has suggested that many specialisms "gained [their] initial and primary justification as a form of knowledge production and dissemination". ${ }^{80}$ I cannot make such a claim for sports medicine, since, although teaching and research became key to the process of specialty formation, these were a consequence of the structure of specialty recognition in the UK, rather than acting as direct drivers for reform in and of themselves. The provision of a diploma, or other qualification, in sports medicine could act as a clear marker of expertise, and so when there was demand for such a qualification, there was a rush by a variety of organizations to provide (and therefore control) it. By 1989 any doctor interested in sports medicine had three different postgraduate diplomas to choose from; a part-time BAS(E)M course, a full-time partly BAS(E)M-sponsored course at the National Institute of Sports Medicine, and one under the aegis of the Institute of Sports Medicine at the London Hospital. Any of these, with the addition of a dissertation and some other requirements, would permit a candidate to sit exams and qualify with a Diploma in Sports Medicine recognized by the Society of Apothecaries. ${ }^{81}$ A "necessarily distinct training path" is one requirement for specialty recognition in the UK, so once this was in place it was possible for sports medicine organizations to campaign for sports medicine to become a formal specialty. ${ }^{82}$ An Intercollegiate Academic Board of Sport and Exercise was put together in 1998, and created a working party to apply for specialty status in 2003. Their application was submitted in 2004, and the specialty of Sport and Exercise Medicine was formally recognized the following year. ${ }^{83}$

Between 1970 and the mid-1980s the representatives of sports medicine in Britain changed direction on the question of specialty formation. This article has discussed in detail two factors in that shift; first, the Sports Council's SIC scheme, which drew political attention to a definition of sports medicine (or rather, sports injuries) that did not suit the needs of many sports medicine practitioners. Second was the issue of insurance and of practitioner-only organizations, where registered medical practitioners demanded proper representation to help prove their expertise and to protect their professional interests. These examples should demonstrate that the specialization of sports medicine was a many-faceted process - it was about economics, and authority, and status, and NHS policy, and major social changes in leisure and health consumption.

British sports medicine did not face organized forms of opposition, suggesting alternative technical interventions, treatment modalities, or even sources of overall expertise and

\footnotetext{
${ }^{80}$ Weisz, op. cit., note 3 above, p. xxi.

${ }^{81}$ Anon., 'Diploma in sports medicine (Society of Apothecaries)', BJSM, 1989, 23: 61-2.

${ }^{82}$ NA, MH166/1394, letter from W M Hollyhock to McGregor, 9 Nov. 1971.
} 


\section{Vanessa Heggie}

authority. (All the SICs were, after all, run by registered medical practitioners who relied on the Royal College of Surgeons or of Physicians for ultimate sanction.) No one organization ever seemed to be, for more than a brief moment, a serious threat to the BAS(E)M's role as the major representative and spokes-organization of sports medicine practitioners in the UK. There was a danger of the complete disappearance and disaggregation of the BAS(E)M into a federalist structure, of sports medicine being absorbed into the generalized health care for the mass of the population, and of a specialism fit only for a tiny pool of elite athletic bodies. These were not groundless fears. The scenario played out in the late twentieth century in the USA resulted in a situation where sports medicine now exists only as a set of fractured sub-disciplines, not a holistic specialty. ${ }^{84}$

The Sports Council's SIC scheme acted to highlight the vulnerabilities of sports medicine in the 1970s. Issues of expertise, education and authority were brought to the fore, and mapped out over well-established tensions between hospital and community, consultant and general practitioner, doctors and the professions allied to medicine. Sports medicine could retreat into private practice, cling to the elite athletic body which had defined sports medicine since the 1950s, or it could find a way of justifying its place in the NHS and of embracing both the leisure revolution and the new idea of exercise as a curative and preventive medical intervention. The organizations of British sports medicine explicitly and deliberately took the latter path: "We must look beyond the physiologically interesting freaks of elite sport", read a British Journal Sports Medicine editorial in 1993, "to lay claim to the broader field of sports medicine with its general health benefits." ${ }^{85}$ That sports medicine managed to change quite radically the internal rhetorical justification for its expertise while maintaining its integrity was made possible by its embracing the formal structures, academic systems and registration which had earlier been rejected.

The specialization of sports medicine was therefore a complicated process of external and internal pressures, of economic, social, and political needs. Perhaps the only comparable study is that of the specialization of clinical genetics, because although Peter Coventry and John Pickstone do not specifically delineate the same pattern of specialty formation as I have outlined here, there is a clear similarity. ${ }^{86}$ Clinical genetics was a discipline which grounded itself in a scientific justification in the 1950s and 1960s, and, like sports medicine, successfully expanded the territory of its expertise in the 1970s. This, as is the case for sports medicine, was driven by the internal politics of the NHS's changing health policy. I would add to this account that shifting public attitudes, and demands for genetic testing, also influenced change. That there are similarities between what appear to be two quite differently organized and justified biomedical specialties suggests that the information given on one aspect of late-twentieth-century specialization may prove useful in considerations and reconsiderations not only of the process of specialization in medicine as a whole, but also in the sciences more broadly. ${ }^{87}$

\footnotetext{
${ }^{84}$ It is a sub-specialty in the larger fields of emergency medicine, family medicine, internal medicine, orthopaedic surgery, paediatrics and physical medicine and rehabilitation.

${ }^{85}$ Editorial, 'Sports medicine and national fitness', BJSM, 1993, 27: 3.
}

\footnotetext{
${ }^{86}$ Coventry and Pickstone, op. cit., note 6 above.

${ }^{87}$ Especially since even recent studies on specialty formation in the sciences eschew references to material from specialization in medicine; see $\mathrm{K}$ Brad Wray, 'Rethinking scientific specialization', Soc. Stud. Sci., 2005, 35: 151-64.
} 